\title{
Inorganic phytoplankton nutrients in the Wadden Sea areas off Schleswig-Holstein. I. Dissolved inorganic nitrogen
}

\author{
P. Martens \\ Biologische Anstalt Helgoland (Wadden Sea Institute); D-2282 List/Sylt, \\ Federal Republic of Germany
}

\begin{abstract}
In the summer months of 1984, 1986, 1987 und 1988, several stations off the west coast of Schleswig-Holstein were investigated with regard to the situation of dissolved inorganic nitrogen. An increase in nutrients was observed during the last few years related to a decrease in salinity. This is possibly due to an increased freshwater outflow caused by higher rainfall during recent summers.
\end{abstract}

\section{INTRODUCTION}

For more than 13 years, planktological parameters such as zooplankton, phytoplankton and phytoplankton-nutrients have been measured by the Biologische Anstalt Helgoland at different stations in the northern Wadden Sea of Sylt. This is the most northern Wadden Sea area in Germany. It is separated from the southern areas of the German Wadden Sea by the Hindenburg Dam. For this reason, the results of these investigations cannot be extrapolated to the southern Wadden Sea areas, which are influenced by Elbe and Eider to a much greater extent.

In 1984, a series of investigations was started at different stations along the west coast of Schleswig-Holstein to measure trends and gradients in space in the eutrophication of the Wadden Sea areas.

Some of the near-shore stations (Fig. 1) were chosen for this paper to throw light on the subject of dissolved inorganic nitrogen.

\section{MATERIAL AND METHODS}

In the summer months (June to August) of 1984, 1986, 1987 and 1988, investigations were carried out at several stations on the west coast of Schleswig-Holstein (Fig. 1) with respect to different hydrographical parameters. Due to technical reasons, the 1985-cruise took place in spring; the results of the year 1985 cannot, therefore, be compared directly with those of the others and have been omitted here. The following parameters were analysed:

(1) Temperature $\left( \pm 0.05^{\circ} \mathrm{C}_{i}\right.$ reversing thermometer)

(2) Salinity ( $\pm 0.001 \mathrm{~S}$; Guildline-salinometer)

(3) Chlorophyll-a (UNESCO standard method)

(c) Biologische Anstalt Helgoland, Hamburg 


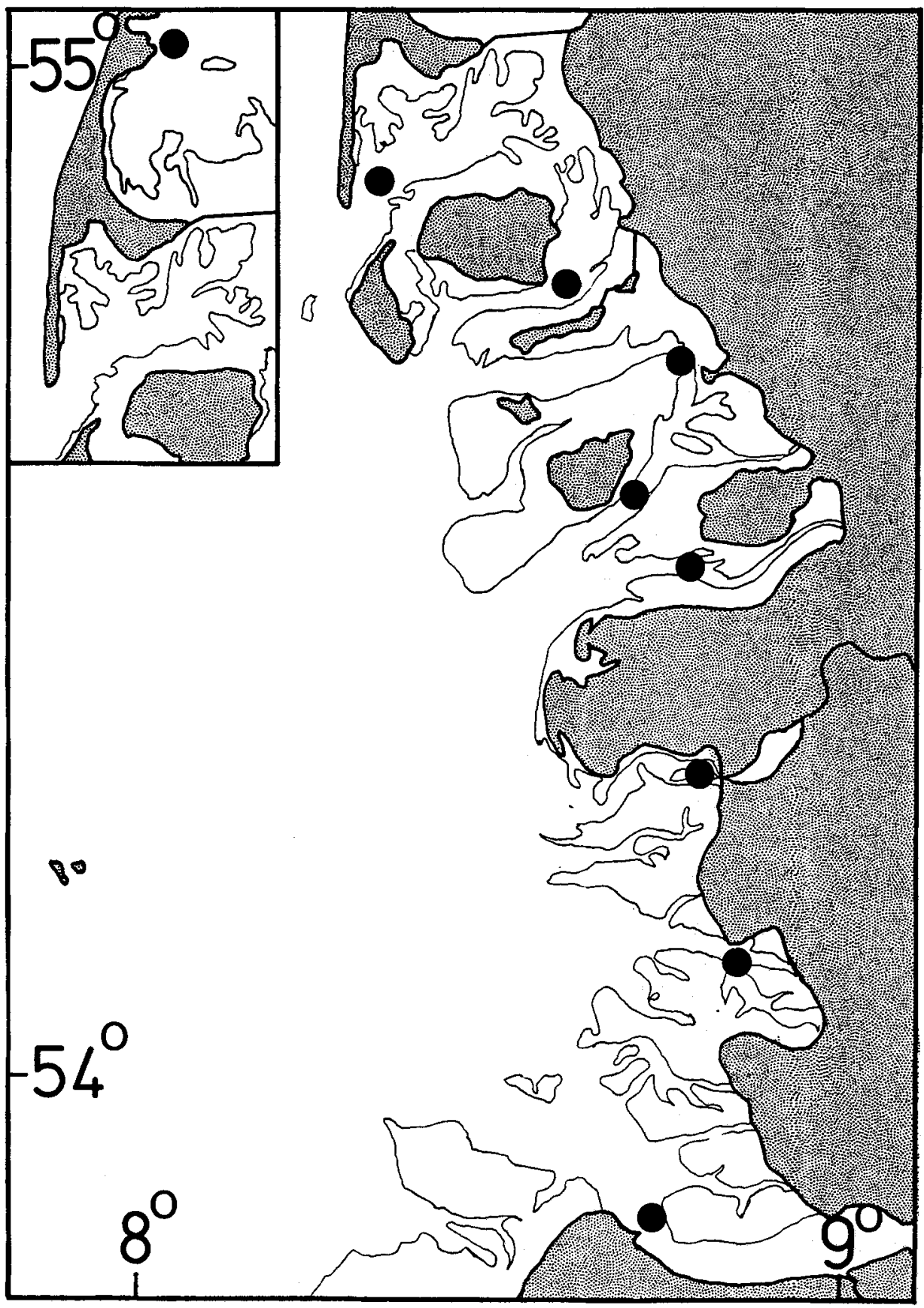

Fig. 1. Position of the stations investigated off the west coast of Schleswig-Holstein (from north to south): List Harbour (inset), Hörnum Deep, Föhrer Ley, Hamburger Hallig, Pellworm Harbour, Hever Stream, Eider Sperrwerk (Eider estuary), Büsum Harbour and Elbe (Buoy 30) 
(4) Meso-zooplankton ( $\geq 80 \mu \mathrm{m})$

(5) $\mathrm{pH}( \pm 0.01 \mathrm{pH})$

(6) Dissolved oxygen (Winkler-method)

(7) Phytoplankton-nutrients $\left(\mathrm{PO}_{4}, \mathrm{Si}, \mathrm{NH}_{4}, \mathrm{NO}_{2}, \mathrm{NO}_{3}\right)$ (Graßhoff, 1976)

(8) Seston-dry weight

(9) Particulate organic carbon (POC) and nitrogen (PON)

The meteorological station List provided weather data. Daily mean values of rainfall during the periods of investigation were computed on the basis of quarterly rainfall measurements. There were no significant differences between these quarterly, monthly and weekly mean values (Fig. 5). The measurements of the meteorological station List were taken as representative for the whole west coast of Schleswig-Holstein.

The hydrographical samples were taken with Transparent-Plastic-Nansen(TPN)water samplers (system Hydrobios) at the surface. Samples were taken in turbulently mixed tidal gullies where no stable stratification occurs (Hickel, 1975; Martens, unpubl. data).

\section{RESULTS}

Figure 1 shows the position of the stations on the west coast of Schleswig-Holstein. The low draft $(0.75 \mathrm{~m})$ of the R.V. "Mya" made these near-shore stations possible.

Figure 2 shows the nitrogen content at the 5 northern stations. List Harbour is one of the most frequently investigated stations in the northern Wadden Sea of Sylt (Martens, 1989). During the five years of investigation no clear trend was seen; the nitrogenconcentrations in List Harbour are the lowest of all the stations visited.

At "Hörnum-Deep", south of the Hindenburg-Dam, there is a positive trend in nitrate; the same holds true for the station "Föhrer Ley". Here, the higher nitrogen concentration of more than $12 \mu$ gat $1^{-1}$ was found as early as 1987 . Similar results were recorded at the stations "Hamburger Hallig", "Pellworm Harbour" and "Hever-stream" (Fig. 3), in the vicinity of the southern part of the Wadden Sea. Compared to List Harbour, they all have relatively high nitrogen concentrations of 10 to $20 \mu$ gat $1^{-1}$. Ammonium shows the same rising tendency as nitrate.

Very high nitrate concentrations, with rising tendency, can be found at "Eider Sperrwerk", the estuary of the river Eider (Fig. 3). Concentrations of up to $70 \mu$ gat nitrogen $1^{-1}$ can be found in summer. This is comparable to winter values in the northern Wadden Sea of Sylt.

At the Station "Büsum Harbour" (Fig. 3) the same high concentrations could be found, with rising tendency. A station at the estuary of the river Elbe, near Cuxhaven (Fig. 3), showed the highest nitrate-concentrations. No tendency is to be seen; concentrations in 1988 are even lower than in 1984.

Figure 4 shows the salinity at the stations "List Harbour", "Hörnum Deep", EiderSperrwerk" and "Büsum Harbour" during the time of investigation. The stations with the highest nitrogen-increase show the greatest salinity-decrease. In contrast, salinity and nitrogen at List Harbour are positively related (Figs 2 and 4).

Figure 5 shows the mean daily rainfall at the times of investigation. A rising tendency can clearly be seen. The graphs showing rainfall and nitrogen-concentration at EiderSperrwerk are nearly identical. 


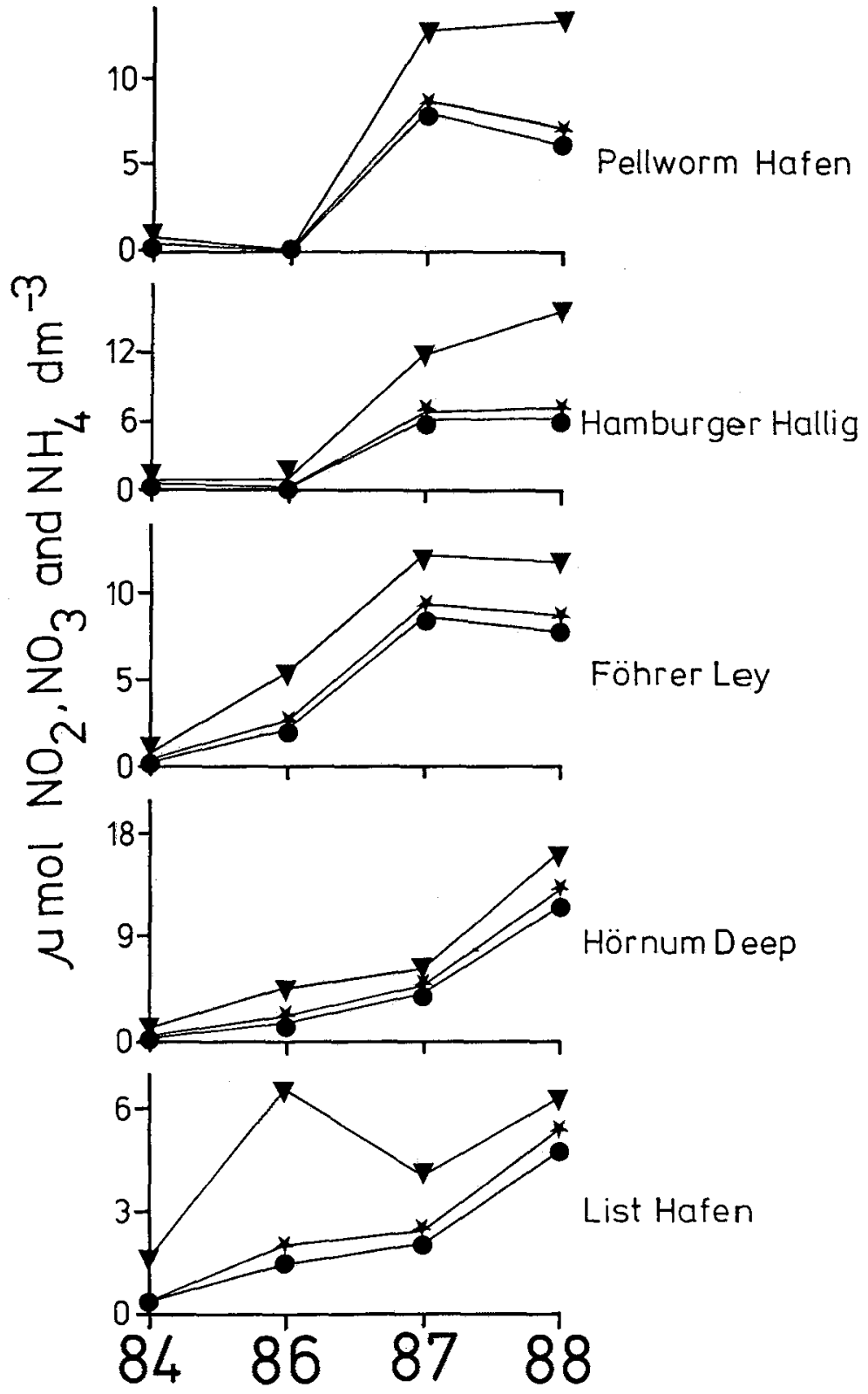

Fig. 2. Concentration of $\mathrm{NH}_{4}, \mathrm{NO}_{2}$ and $\mathrm{NO}_{3}$ at the stations List Harbour, Hörnum Deep, Föhrer Ley, Hamburger Hallig and Pellworm Harbour in the summer of the years 1984, 1986, 1987 and 1988. $\star-\star=$ Nitrate; $\bullet-\bullet=$ Nitrite; $\boldsymbol{\square} \longrightarrow$ = Ammonium 


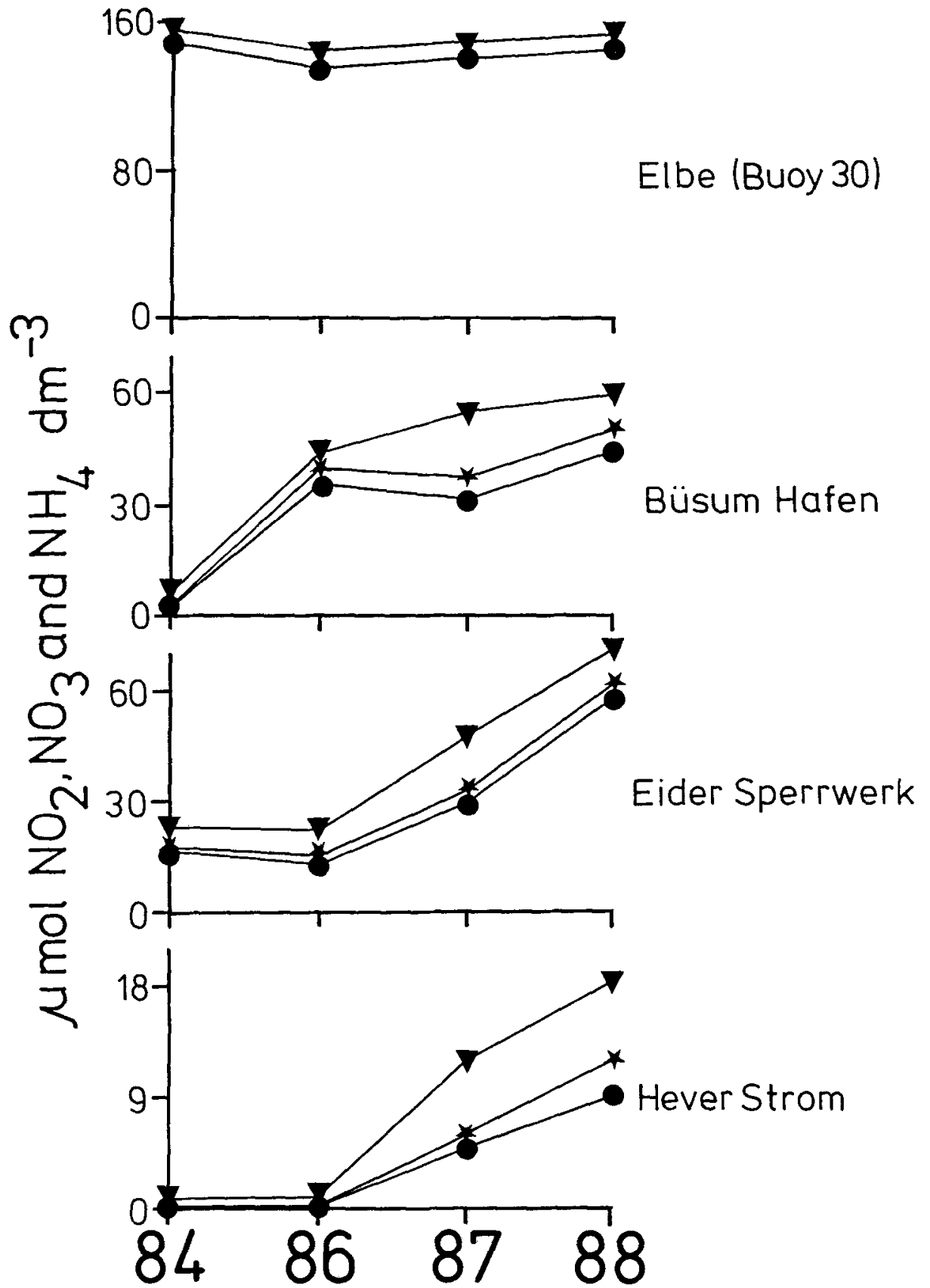

Fig. 3. Concentration of $\mathrm{NH}_{4}, \mathrm{NO}_{2}$ and $\mathrm{NO}_{3}$ at the stations Hever Stream, Eider Sperrwerk, Büsum Harbour and Elbe (Buoy 30) in the summer of the years 1984, 1986, 1987 and 1988. $\star-\star=$ Nitrate; $\bullet-$ Nitrite; $\nabla-\nabla=$ Ammonium 


\section{DISCUSSION}

Trends, in the statistical sense, are continual changes of a system over a "long" timeperiod (Kendall \& Stuart, 1976). So, talking about trends in the present paper is rather misleading. Only the results of one season, in this case the summer, during four different

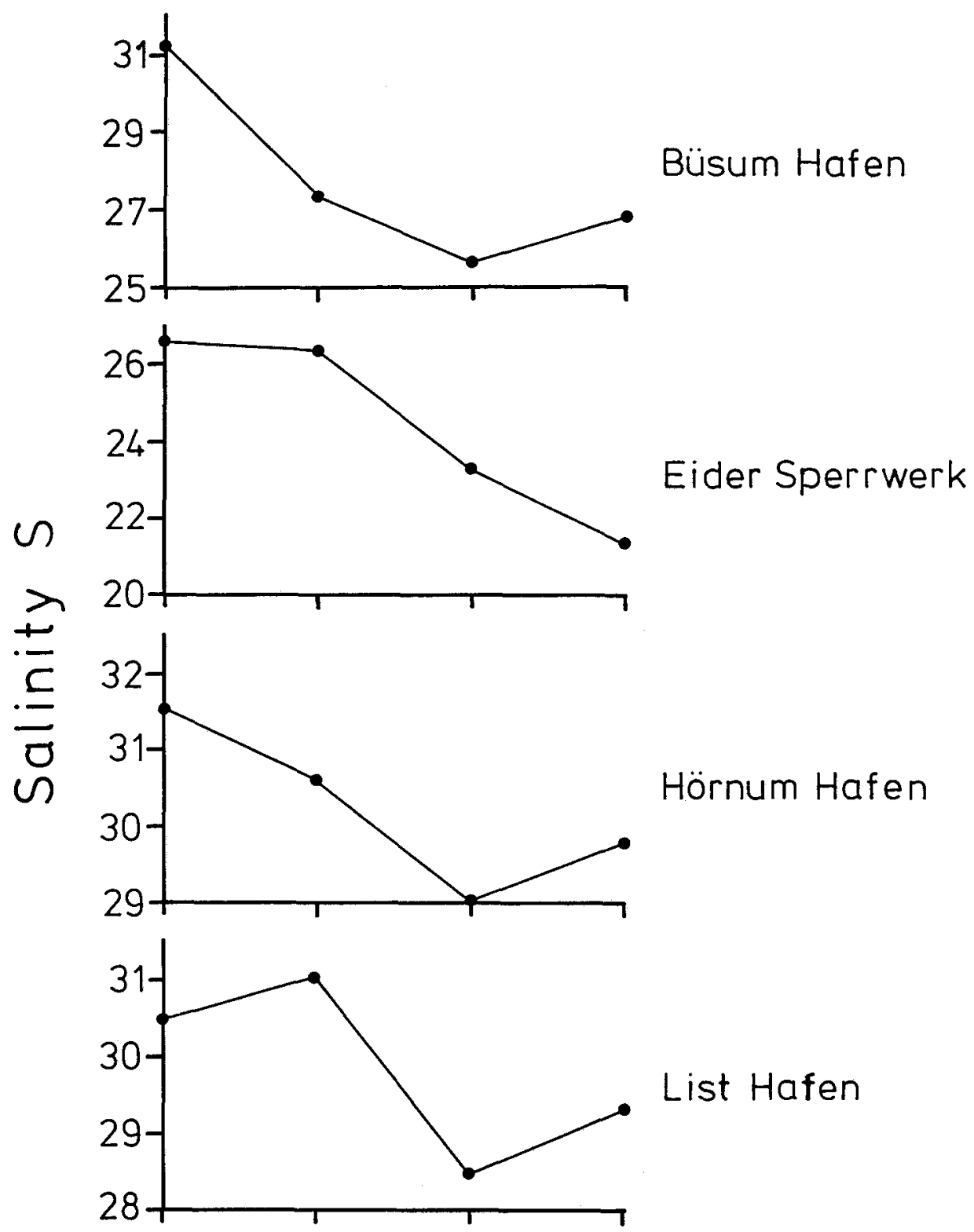

Fig. 4. Salinity (S) at the stations List Harbour, Hörnum Harbour, Eider Sperrwerk and Büsum Harbour in the summer of the years 1984, 1986, 1987 and 1988 


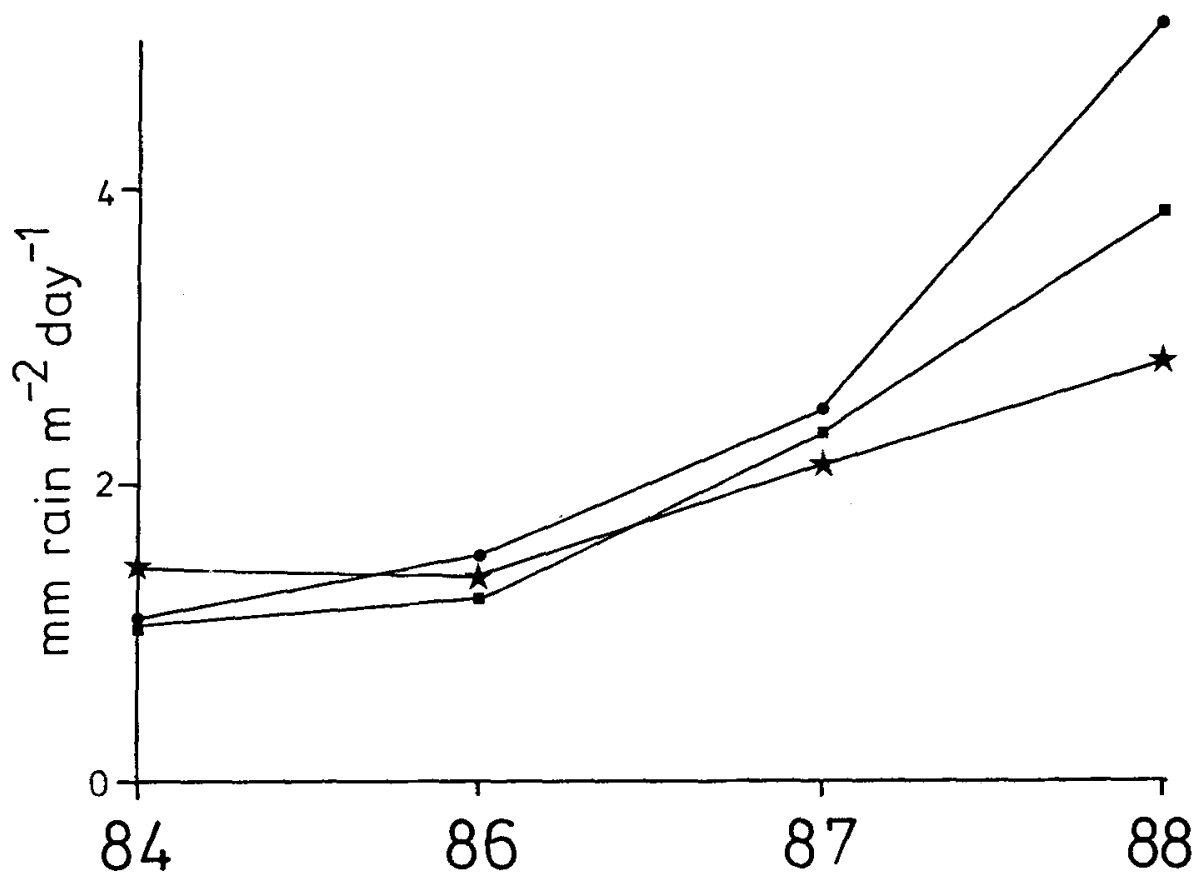

Fig. 5. Mean values of rainfall $\left(\mathrm{mm} \mathrm{m}^{2} \mathrm{day}^{-1}\right)$ in List during the periods of investigation. mean value of 1 week; $\star-\star=$ mean value of 1 month; $1-\square=$ mean value of 3 months

years, are shown here. The present information would be of minor value were it not confirmed by several other investigations. As early as 1978, Hagmeier and Lucht \& Gillbricht showed a rising tendency in phosphate-concentrations in the inner German Bight during first statistical analyses of the Helgoland-Reede measurements (the longest time series in German biological oceanography). A deeper statistical analysis of this time series, up to the year 1984, by Radach \& Berg (1986) shows this trend in addition for nitrate and nitrite, whereas silicate and ammonium had a decreasing tendency.

The above development is related to an increase in the amount of river Elbe outflow, which has a marked influence on the nutrient-concentrations in the German Bight, as shown e.g. by Brockmann \& Eberlein (1986). This is confirmed by a negative correlation between salinity and nitrate.

A tendency towards rising nutrient-levels can be found even in the shallow coastal waters. A marked phosphate-increase in the northern Wadden Sea of Sylt is shown by Hickel (1989). Martens (1989) gives similar results for the same area for nitrite, nitrate and silicate. The present paper shows that the Wadden Sea areas south of Sylt are no exceptions. However, they have at least one special feature. The German Bight is dominated by the outflow of the river Elbe. In the Wadden Sea areas investigated here, the additional influence of the river Eider can be seen.

No relation between rainfall in the German Bight, Elbe-outflow and nutrientconcentration could be found by Radach \& Berg (1986). This is not very astonishing, since the catchment basin of the Elbe stretches far to the east. When comparing the rainfall 
measured on Sylt (Fig. 5) with the salinity (Fig. 4) and nitrogen-content (Fig. 3) at the outlet of the river Eider, a clear relationship can be seen: increasing rainfall leads to a decrease in salinity accompanied by an increase in nitrogen.

A direct influence of the rainfall on the nitrogen-concentration, as seems possible in the northern Wadden Sea of Sylt (Martens 1989), is not very likely at the mouth of river Eider. The increase in nitrogen is too great. The most possible explanation is an increase in river Eider outflow causing an increase in the nitrogen content of the coastal waters.

Some measurements were taken in 1987 along the river Eider to prove whether Eider-water contains enough nitrogen to cause such a marked increase in the coastal area. As can be seen from Figure 6, higher nitrogen-concentrations than in the Elbewater at Cuxhaven could be found. Hardly any industry is situated in this area, so the adjacent agriculture is possibly the source. The increased rainfall during recent summers, compared to earlier years, could have led to a higher run-off from the fields.

The stations furthest from the Eider estuary showed the least nitrogen-increase during the last few years, and in the northern Wadden Sea of Sylt a positive relation between salinity and nitrogen could be found, as can be seen by a comparison of Figures 2 and 4.

This was shown earlier by Martens (1982) and is an indication of the import of nutrients into this area, different, for instance, from the Dutch Wadden Sea areas (Postma \& van Bennekom, 1974) with its strong Rhine-influence.

Compared to the northern Wadden Sea of Sylt, the areas to the south of Sylt have an additional nutrient-source - the river Eider, which, related to meteorological changes, has lead to a distinct eutrophication of these coastal areas over the last few years.

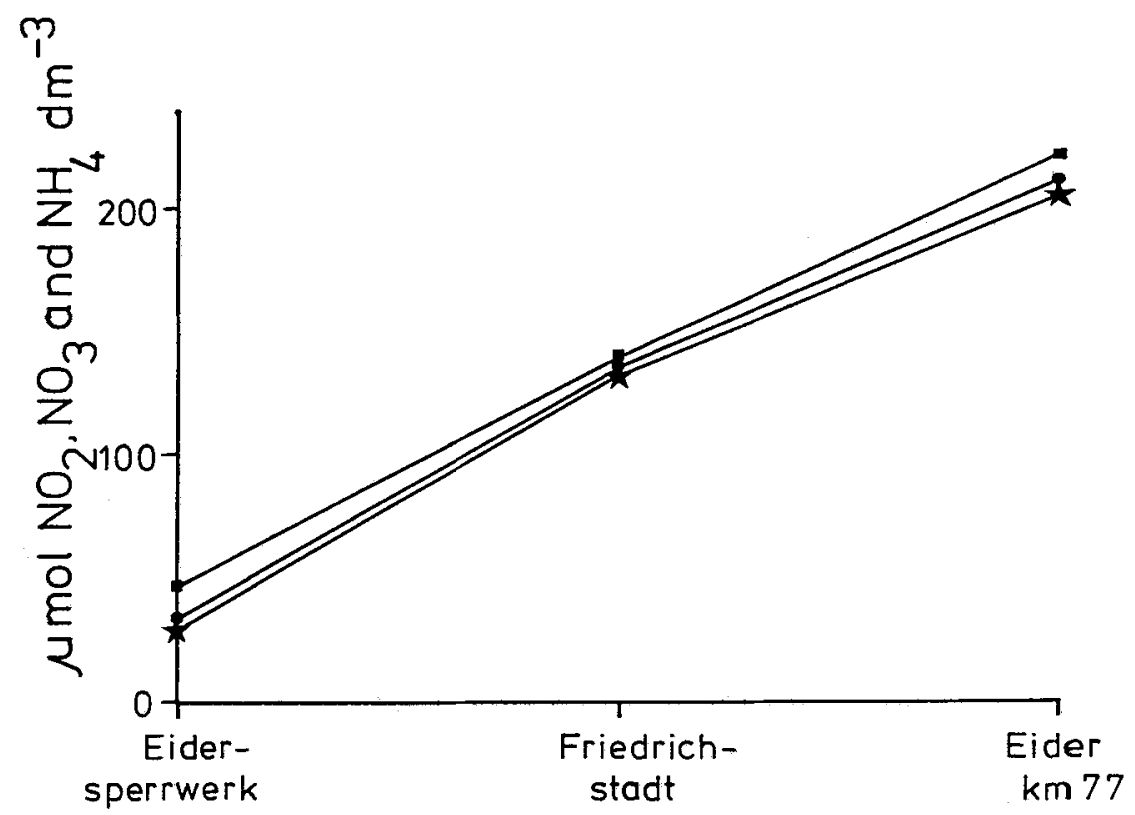

Fig. 6. Concentration of $\mathrm{NH}_{4}, \mathrm{NO}_{2}$ and $\mathrm{NO}_{3}$ at three stations in the river Eider in summer 1987 ( $\mu$ gat

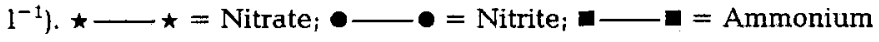


Acknowledgements. Sincere thanks are due to C. Reineke and the crew of the F.K. Mya for technical support even at times when conditions were unfavorable. The staff of the meteorological station List, and of the Deutsche Wetterdienst, support us regularly with meteorological data.

\section{LITERATURE CITED}

Brockmann, U. H. \& Eberlein, K., 1986. River input of nutrients into the German Bight. In: The role of freshwater outflow in coastal marine ecosystems. Ed. by S. Skreslet. Springer, Berlin 231-240.

Graßhoff, K., 1976. Methods of seawater analysis. Verl. Chemie, Weinheim, 317 pp.

Hagmeier, E., 1978. Variations in phytoplankton near Helgoland. - Rapp. P.-v. Reún. Cons. perm. int. Explor. Mer. 172, 361-363.

Hickel, W., 1975. The mesozooplankton of the Wadden Sea of Sylt (North Sea). - Helgoländer Meeresunters. 27, 254-262.

Hickel, W., 1989. Inorganic micronutrients in relation to phytoplankton and the eutrophication in the Wadden Sea of Sylt (German Bight, North Sea). - Proceedings of the $21^{\text {st }}$ European Marine Biology Symposium, Gdansk, Poland (in press).

Kendall, M. \& Stuart, A., 1976. The advanced theory of statistics. Griffin, London, $585 \mathrm{pp}$.

Lucht, F. \& Gillbricht, M., 1978. Long-term observations on nutrient contents near Helgoland in relation to nutrient input of the river Elbe. - Rapp. P.-v. Reún. Cons. int. Explor. Mer. 172, 358-360.

Martens, P., 1982. Zur Biologie des Planktons des Königshafens (Nordsylter Wattenmeer). - Helgoländer Meeresunters. 35, 243-251.

Martens, P., 1989. On trends in the nutrient-concentration in the northern Wadden Sea of Sylt. Helgoländer Meeresunters. (in press).

Postma, H. \& van Bennekom, A. J., 1974. Budget aspects of biologically important chemical compounds in the Dutch Wadden Sea. - Neth. J. Sea Res. 8, 312-318.

Radach, G. \& Berg, J., 1986. Trends in den Konzentrationen der Nährstoffe und des Phytoplanktons in der Helgoländer Bucht (Helgoland Reede Daten). - Ber. Biol. Anst. Helgoland 2, 1-63. 